\title{
Note
}

\section{Observation of an Eastern Wolf (Canis sp. cf. lycaon) Caching Food in a Sphagnum Bog in Algonquin Provincial Park, Ontario}

\author{
PATRICK D. Moldowan ${ }^{1,2,3}$ and Hugo KITCHING ${ }^{1}$ \\ ${ }^{1}$ Algonquin Wildlife Research Station, P.O. Box 49, Whitney, Ontario K0J 2M0 Canada \\ ${ }^{2}$ Department of Ecology and Evolutionary Biology, University of Toronto, 25 Willcocks Street, Toronto, Ontario M5S 3B2 Canada \\ ${ }^{3}$ Corresponding author: pmoldowan1@laurentian.ca
}

Moldowan, Patrick D., and Hugo Kitching. 2016. Observation of an Eastern Wolf (Canis sp. cf. lycaon) caching food in a Sphagnum bog in Algonquin Provincial Park, Ontario. Canadian Field-Naturalist 130(4): 351-354.

We report summer caching of a partial carcass of a White-tailed Deer (Odocoileus virginianus) fawn by an Eastern Wolf (Canis sp. cf. lycaon) in a Sphagnum bog in Algonquin Provincial Park, Ontario, Canada. The microhabitat conditions in bogs (i.e., low temperature, acidity, and organochemical compounds) likely inhibit food spoilage, making bogs potentially important sites for food caching. Wolves in Algonquin Park experience low summer food availability and high pup mortality from starvation. Caches likely serve as necessary reserve food stores for adults and pups. Recent research has shown that wetland habitats are important den and rendezvous sites for Algonquin Eastern Wolves based on prey availability and, we suggest, perhaps for food storage and accessibility. This caching behaviour was recorded on video. We recommend that future research investigate Eastern Wolf selection of food-caching sites, as a complement to other spatial ecology studies.

Key Words: Bog; Canis lycaon; Canis sp. cf. lycaon; Eastern Wolf; food cache; Odocoileus virginianus; prey; Sphagnum; Whitetailed Deer

Food caching is an important strategy used by animals to overcome periods of food scarcity. Food-caching behaviour has been observed in multiple canid species, including Gray Wolves (Canis lupus; Murie 1944; Mech 1970; Adams et al. 1995; Mech and Adams 1999; Schultz 2010; Nelson 2011; Nelson and Mech 2011), Coyote (C. latrans; Knowlton et al. 1999; Way and Cabral 2009), Red Fox (Vulpes vulpes; Mech 1967, 1970; Macdonald 1976; Maccarone and Montevecchi 1981), Arctic Fox (V. lagopus; Maccarone and Montevecchi 1981, citing personal communication with D. Macdonald), and Gray Fox (Urocyon cinereoargenteus; Fox 1971). Canids cache a wide variety of food items in a diversity of microhabitats (Vander Wall 1990) and are known to do so as pups and adults (Phillips et al. 1990b, as cited by Packard 2003). Eggs of ground-nesting birds (Maccarone and Montevecchi 1981), partly consumed prey, regurgitated food (Mech and Adams 1999; Mech et al. 1999), and/or inanimate objects (Nelson and Mech 2011) may be buried in snow (Murie 1944; Cowan 1947; Mech 1970; Adams et al. 1995; Schultz 2010; Nelson 2011; Nelson and Mech 2011), underground in shallow surface pits or dens, rock crevices, mud, leaf litter, or rotting logs (Young 1944; Cowan 1947; Mech 1988; Mech et al. 1998; Nelson and Mech 2011), at bed sites (Nelson and Mech 2011), or remain in situ with individuals revisiting the site to continue feeding (Mech 1970). However, most records of prey caching among wolves are limited to caching in snow (e.g., Adams et al. 1995; Mech et al. 1998; Nelson 2011; Nelson and Mech 2011). Reports describing caching in seasons oth- er than winter tend to be vague about the local cache environment (e.g., Cowan 1947; Macdonald 1976; Nelson and Mech 2011), which limits inference about the characteristics of food-cache sites. Here, we document an observation of an Eastern Wolf (Canis sp. cf. lycaon) caching the partial carcass of a White-tailed Deer (Odocoileus virginianus) fawn in a Sphagnum bog, a little documented environment for canid food caching with relevance to food preservation and the species' spatial ecology.

Eastern Wolves are largely restricted to Algonquin Provincial Park and the surrounding area of central Ontario and Quebec, forming a genetically distinct population (Rutledge et al. 2010, 2012; Benson et al. 2012). The species is threatened in Canada (COSEWIC 2015) and Ontario (COSSARO 2016). Recent genetic and morphological evidence has demonstrated Eastern Wolf hybridization with Coyotes (C. latrans) and Gray Wolves (C. lupus) in Algonquin Park and adjacent regions (Rutledge et al. 2010; Benson et al. 2012; COSEWIC 2015; COSSARO 2016).

Our observation took place at Broadwing Lake $\left(45.59806^{\circ} \mathrm{N}, 78.52806^{\circ} \mathrm{W}, \mathrm{WGS} 84\right)$ in the Wildlife Research Area of western Algonquin Park. The region is characterized by upland hardwood forest dominated by Sugar Maple (Acer saccharum Marshall), Yellow Birch (Betula alleghaniensis Britton), and Eastern Hemlock (Tsuga canadensis (L.) Carrière) atop the Precambrian shield of the Algonquin dome (Forbes and Theberge 1993). Broadwing Lake is approximately 5.8 ha in open water area with an additional 1.9 ha of riparian, floating

A contribution towards the cost of this publication has been provided by the Thomas Manning Memorial Fund of the Ottawa Field-Naturalist's Club. 
bog characterized by Sphagnum moss, Leatherleaf (Chamaedaphne calyculata (L.) Moench), and Large Cranberry (Vaccinium macrocarpon Aiton). The lake is surrounded by Black Spruce (Picea mariana (Miller) Britton, Stems \& Poggenburgh) and hardwood forest.

On 5 June 2013 at about 0945 Eastern Daylight Time, a single Eastern Wolf was observed exiting the forest and crossing the Sphagnum bog area on the western side of Broadwing Lake. Carrying an unidentified prey item in its mouth, the wolf proceeded to the centre of the bog before dropping the prey. Over the course of 2-3 minutes the wolf dug at the bog mat with its forefeet, deposited the prey item in the depression, and covered the cavity with forward strokes of its downturned muzzle, packing with the forelimbs and muzzle (Video S1). After the prey was buried, the wolf retreated back to the forest.

When the wolf had left the vicinity, one of us (H.K.) visited the site and uncovered the food cache. The partial carcass of a White-tailed Deer fawn was buried at a depth of approximately $10-15 \mathrm{~cm}$ in saturated Sphagnum moss. The carcass consisted of the anterior half of the fawn, including the head, neck, two forelimbs, and thoracic cavity with ribcage. The fawn was eviscerated. Fresh blood was present on the carcass indicating that the predation was recent. The fawn carcass was not weighed or measured. No additional monitoring of the cache site was conducted.

To our knowledge, this is one of the first descriptions of the use of a bog site for food caching by a canid and the first record of food caching by an Eastern Wolf. The observed caching behaviour was similar to that described for Gray Wolves (Murie 1944), Arctic Grey Wolves (C. lupus arctos; Mech 1988), Coyotes (Phillips et al. 1990b, 1991; Knowlton et al. 1999), and Red Foxes (Macdonald 1976). This caching sequence, including forelimb digging and substrate scooping and tamping with the snout, is highly stereotyped in canids (Phillips et al. 1990a,b, 1991). Although we have characterized the observed canid as a putative Eastern Wolf, we recognize that the animal could have been admixed with a combination of ancestry derived from Eastern Wolf, Coyote, and/or Gray Wolf (which could only be affirmed through genetic analysis; Rutledge et al. 2010; Benson et al. 2012).

Bogs provide a unique set of environmental traits that may promote food preservation (Hoppe 1977, cited in Elgmork 1982; Verhoeven and Liefveld 1997). First, sub-surface temperatures in bogs remain cool during mid-summer providing natural refrigeration of the cache. For instance, at a depth of 10-15 cm, temperatures among the saturated Sphagnum moss measure 4- $6^{\circ} \mathrm{C}$, approximately $20^{\circ} \mathrm{C}$ cooler than the ambient daytime air temperature during midsummer in Algonquin Park (P.D.M., unpublished data). In addition, the low pH of Sphagnum bogs (typically 4.0-4.8; Gorham and Janseens 1992) may inhibit spoilage of the cache. Organochemical compounds found in Sphagnum, such as phenolic acids, exhibit bactericide and fungicide properties, thereby suppressing decomposition (Hoppe 1977, cited in Elgmork 1982; Verhoeven and Liefveld 1997).

Mech (1970) speculated that wolves lose a large portion of cached food to scavengers. Domestic Dogs $(C$. lupus familiaris) are adept at finding wolf food caches (Cowan 1947) and scavengers frequenting wolf kill sites, such as Red Foxes, Black Bears (Ursus americanus), Ravens (Corvus corax), and insects, are capable of locating and exploiting food caches (Murie 1944; Peterson and Ciucci 2003). Food cached in bogs may be difficult to detect because of the delayed onset of spoilage and, thus, may be less likely to be lost to scavengers. Gray Wolves in Denali National Park, Alaska, have been reported caching a Caribou (Rangifer taran$d u s$ ) calf in the muddy substrate of a flowing stream, and several cached calves have been found submerged along the edge of spruce bogs (Mech et al. 1998). According to Egmork (1982), half of the caching sites used by Brown Bear (Ursus arctos) in Norway were Sphagnum bogs.

The diet of wolves in Algonquin Park consists largely of American Beaver (Castor canadensis), Moose (Alces americanus), and White-tailed Deer (Kolenosky 1972; Voigt et al. 1976; Forbes and Theberge 1996; Benson and Patterson 2013). Young animals are particularly vulnerable to wolf predation (Pimlott 1975; Voigt et al. 1976; Mech and Petersen 2003; Mech et al. 2015). Based on the relative size of the fawn carcass and date of the caching observation, the prey fawn was likely $<1$ month old (in Algonquin Park, White-tailed Deer fawning begins in late May; Voigt 1976). Birth weight of White-tailed Deer fawns ranges from 1.8 to $3.8 \mathrm{~kg}$ (Smith 1991; Geist 1998). Food consumption rates have been estimated at $0.10 \mathrm{~kg} / \mathrm{kg}$ wolf/day $(2.9$ $\mathrm{kg} /$ wolf/day) in Algonquin Park (Kolenosky 1972) and $0.14 \mathrm{~kg} / \mathrm{kg}$ wolf $/$ day $(5.4 \mathrm{~kg} /$ wolf $/$ day) based on a review of studies across North America (Peterson and Ciucci 2003). Thus, given the consumption rates of wolves, the deer fawn was likely killed and partly consumed by the single wolf. If multiple wolves had been involved, the small carcass would likely have been consumed in its entirety. This conclusion is supported by findings from Benson and Paterson (2015) that wolves in western Algonquin Park spend most of their time apart from packmates and, presumably, hunting alone during non-winter months. Furthermore, wolves are more likely to cache food in the absence of conspecifics (Townsend 1996).

Caches serve as reserve food sources in the event that a hunt is unsuccessful, and they are especially important in providing a regular food supply for pups (Mech 1988; Mech et al. 1998). In western Algonquin Park, infrequent predation of Moose and low deer abundance in summer (Forbes and Theberge 1996; Theberge et al. 1996; Benson et al. 2015), as well as low American Beaver densities (Benson et al. 2013), con- 
tribute to food limitation for wolves. This food limitation appears to pose a serious risk for pup survival (Benson et al. 2013, 2015). High pup mortality in western Algonquin Park resulting from starvation (Benson et al. 2013) illustrates the importance of cached food stores during summer, particularly when adult wolves are hunting and leave pups at dens or bog rendezvous sites (Benson et al. 2015). Recent research in Algonquin Park has demonstrated that wolf packs that had lost pups to starvation selected dens and rendezvous sites closer to wetlands than other packs (Benson et al. 2015). Thus, home-sites close to bog habitats may confer advantages not only for hunting (Benson et al. 2015), but also for food storage and accessibility.

Sphagnum bog habitats, given their spoilage-inhibiting environmental conditions, seem to be suitable caching sites for a diversity of food-caching species in northern regions. However, the importance of bogs as food-caching sites remains to be studied. Cryptic caching behaviour and location of caches (Mech et al. 1998) make study difficult. We recommend that future reports of food caching in the wild be accompanied by detailed descriptions of behaviour and/or the local cache environment (e.g., Elgmork 1982) so that inferences can be made about cache structure and conditions, which may, in turn, inform aspects of species' biology (e.g., interspecific interactions, habitat use). Future research may investigate the potential relation between den and rendezvous site selection in Eastern Wolves related to the spatial distribution of cache sites.

\section{Acknowledgements}

We thank the Algonquin Wildlife Research Station, J. Hoare, B. Steinberg, and Ontario Parks for logistical and in-kind support. We also thank M. G. Keevil for assistance with manuscript preparation and special thanks to J. F. Benson for review and sharing of his Algonquin wolf expertise. Thank you to T. S. Jung, D. Lepitzki, S. Garland, and one anonymous reviewer whose comments improved this manuscript.

\section{Literature Cited}

Adams, L. G., B. W. Dale, and L. D. Mech. 1995. Wolf predation on Caribou calves in Denali National Park, Alaska. Pages 245-260 in Ecology and Conservation of Wolves in a Changing World. Edited by L. N. Carbyn, S. H. Fritts, and D. R. Seip. Canadian Circumpolar Institute, Edmonton, Alberta, Canada.

Benson, J. F., B. R. Patterson, and T. J. Wheeldon. 2012. Spatial genetic and morphologic structure of wolves and coyotes in relation to environmental heterogeneity in a Canis hybrid zone. Molecular Ecology 21: 5934-5954.

Benson, J. F., and B. R. Patterson. 2013. Moose (Alces alces) predation by Eastern Coyotes (Canis latrans) and Eastern Coyote $\times$ Eastern Wolf (Canis latrans $\times$ Canis lycaon) hybrids. Canadian Journal of Zoology 91: 1-5.

Benson, J. F., and B. R. Patterson. 2015. Spatial overlap, proximity, and habitat use of individual wolves within the same packs. Wildlife Society Bulletin 39: 31-40.
Benson, J. F., K. J. Mills, K. M. Loveless, and B. R. Patterson. 2013. Genetic and environmental influences on pup mortality risk for wolves and coyotes in a Canis hybrid zone. Biological Conservation 166: 133-141.

Benson, J. F., K. J. Mills, K. M. Loveless, and B. R. Patterson. 2015. Resource selection by wolves at dens and rendezvous sites in Algonquin Park, Canada. Biological Conservation 182: 223-232.

COSEWIC (Committee on the Status of Endangered Wildlife in Canada). 2015. COSEWIC assessment and status report on the Eastern Wolf Canis sp. cf. lycaon in Canada. COSEWIC, Ottawa, Ontario, Canada.

COSSARO (Committee on the Status of Species at Risk in Ontario). 2016. Ontario species at risk evaluation report for Algonquin Wolf (Canis sp.), an evolutionary significant and distinct hybrid with Canis lycaon, C. latrans, and $C$. lupus ancestry. 4. Summary of Ontario status. COSSARO, Toronto, Ontario, Canada. Accessed 19 September 2016. https://www.ontario.ca/page/ontario-species-risk-evaluation -report-algonquin-wolf-canis-sp-evolutionarily-significant -and\#section-4.

Cowan, I. M. 1947. The Timber Wolf in the Rocky Mountain national parks of Canada. Canadian Journal of Research 25: 139-174.

Elgmork, K. 1982. Caching behavior of Brown Bears (Ursus arctos). Journal of Mammalogy 63: 607-612.

Forbes, G. J., and J. B. Theberge. 1993. Multiple landscape scales and winter distribution of Moose, Alces alces, in a forest ecotone. Canadian Field-Naturalist 107: 201-207.

Forbes, G. J., and J. B. Theberge. 1996. Response by wolves to prey variation in central Ontario. Canadian Journal of Zoology 74: 1511-1520.

Fox, M. W. 1971. Behaviour of Wolves, Dogs, and Related Canids. Harper \& Row Publishers, New York, New York, USA.

Geist, V. 1998. White-tailed Deer and Mule Deer. Pages 255 414 in Deer of the World: Their Evolution, Behaviour, and Ecology. Edited by V. Geist. Stackpole Books, Mechanicsburg, Pennsylvania, USA.

Gorham, E., and J. Janssens. 1992. Concepts of fen and bog re-examined in relation to bryophyte cover and the acidity of surface waters. Acta Societatis Botanicorum Poloniae 61: 7-20.

Hoppe, H. A. 1977. Drogenkunde, Band 2: Gymnospermen, Kryptogamen, Tierische Drogen. Eighth Edition. Walter de Gruyter, Berlin, Germany.

Knowlton, F. F., E. M. Gese, and M. M. Jaeger. 1999. Coyote depredation control: an interface between biology and management. Journal of Range Management 52: 398-412.

Kolenosky, G. B. 1972. Wolf predation on wintering deer in east-central Ontario. Journal of Wildlife Management 36: 357-369.

Maccarone, A. D., and W. A. Montevecchi. 1981. Predation and caching of seabirds by Red Foxes (Vulpes vulpes) on Baccalieu Island, Newfoundland. Canadian Field-Naturalist 95: 353-353.

Macdonald, D. W. 1976. Food caching by Red Foxes and some other carnivores. Zeitschrift für Tierpsychologie 42: 170-185.

Mech, L. D. 1967. Telemetry as a technique in the study of predation. Journal of Wildlife Management 31: 492-496.

Mech, L. D. 1970. The Wolf: The Ecology and Behavior of an Endangered Species. Natural History Press, Garden City, New York, USA. 
Mech, L. D. 1988. The Arctic Wolf, Living with the Pack. Voyageur Press, Stillwater, Minnesota, USA.

Mech, L. D., and L. G. Adams. 1999. Killing of a Muskox, Ovibos moschatus, by two wolves, Canis lupus, and subsequent caching. Canadian Field-Naturalist 113: 673-675.

Mech, L. D., L. G. Adams, T. J. Meier, J. W. Burch, and B. W. Dale. 1998. The Wolves of Denali. University of Minnesota Press, Minneapolis, Minnesota, USA.

Mech, L. D., A. Morris, and S. Barber-Meyer. 2015. Whitetailed Deer (Odocoileus virginianus) fawn risk from Gray Wolf (Canis lupus) predation during summer. Canadian Field-Naturalist 129: 368-373.

Mech, L. D., and R. O. Petersen. 2003. Wolf-prey relations. Pages 131-157 in Wolves: Behavior, Ecology, and Conservation. Edited by L. D. Mech and L. Boitani. University of Chicago Press, Chicago, Illinois, USA.

Mech, L. D., P. C. Wolf, and J. M. Packard. 1999. Regurgitative food transfer among wild wolves. Canadian Journal of Zoology 77: 1192-1195.

Murie, A. 1944. The wolves of Mount McKinley. Fauna series 5. National Park Service, United States Department of the Interior, Washington, DC, USA.

Nelson, M. E. 2011. Killing and caching of an adult Whitetailed Deer, Odocoileus virginianus, by a single Gray Wolf, Canis lupus. Canadian Field-Naturalist 125: 162-164.

Nelson, M. E., and L. D. Mech. 2011. Wolves, Canis lupus, carry and cache the collars of radio-collared deer they kill. Canadian Field-Naturalist 125: 67-68.

Packard, J. M. 2003. Wolf behavior: reproductive, social, and intelligent. Pages 35-65 in Wolves: Behavior, Ecology, and Conservation. Edited by L. D. Mech and L. Boitani. University of Chicago Press, Chicago, Illinois, USA.

Peterson, R. O., and P. Ciucci. 2003. The wolf as a carnivore. Pages 104-130 in Wolves: Behavior, Ecology, and Conservation. Edited by L. D. Mech and L. Boitani. University of Chicago Press, Chicago, Illinois, USA.

Phillips, D. P., W. Danilchuk, J. Ryon, and J. C. Fentress. 1990a. Food-caching in Timber Wolves, and the question of rules of action syntax. Behavioural Brain Research 38: $1-6$.

Phillips, D. P., W. Danilchuk, J. Ryon, and J. C. Fentress. 1990b. Stereotypy of action sequence in food caching by Wolves (Canis lupus) and Coyotes (Canis latrans). American Zoologist 30: A107.

Phillips, D. P., J. Ryon, W. Danilchuk, and J. C. Fentress. 1991. Food caching in captive Coyotes: stereotypy of action sequence and spatial distribution of cache sites. Canadian Journal of Psychology 45: 83-91.
Pimlott, D. H. 1975. The ecology of the wolf in North America. Pages 280-285 in The Wild Canids: Their Systematics, Behavioral Ecology and Evolution. Edited by M. W. Fox. Van Nostrand Reinhold, New York, New York, USA.

Rutledge, L., Y. C. J. Garroway, K. M. Loveless, and B. R. Patterson. 2010. Genetic differentiation of Eastern Wolves in Algonquin Park despite bridging gene flow between coyotes and grey wolves. Heredity 105: 520-531.

Rutledge, L., Y., P. J. Wilson, C. F. C. Klütsch, B. R. Patterson, and B. N. White. 2012. Conservation genomics in perspective: a holistic approach to understanding Canis evolution in North America. Biological Conservation 155: 186-192.

Schultz, R. 2010. A case of mistaken identity? International Wolf Magazine 20: 16-17.

Smith, W. P. 1991. Odocoileus virginanus. Mammalian Species 388: 1-13.

Theberge, J. B., M. T. Theberge, and G. Forbes. 1996. What Algonquin Park wolf research has to instruct about recovery in the northeastern United States. Proceedings: Defenders of Wildlife's Wolves of America Conference, 14-16 November 1996, Albany, New York, USA.

Townsend, S. E. 1996. The role of social cognition in feeding, marking and caching in captive wolves, Canis lupus lycaon and Canis lupus baileyi. Ph.D. thesis, University of Colorado, Boulder, Colorado, USA.

Vander Wall, S. B. 1990. Food Hoarding in Animals. University of Chicago Press, Chicago, Illinois, USA.

Verhoeven, J. T. A., and W. M. Liefveld. 1997. The ecological significance of organochemical compounds in Sphagnum. Acta Botanica Neerlandica 46: 117-130.

Voigt, D. R., G. B. Kolenosky, and D. H. Pimlott. 1976 Changes in summer foods of wolves in central Ontario. Journal of Wildlife Management 40: 663-668.

Way, J. G., and R. D. Cabral. 2009. Effects of hierarchy rank on caching frequency in a captive coywolf (Eastern Coyote) Canis latrans $\times$ lycaon, pack. Canadian FieldNaturalist 123: 173-175.

Young, S. P. 1944. The wolves of North America, Part I: their history, life habits, economic status, and control. Pages 1385 in The Wolves of North America. Edited by E. P. Young and E. A. Goldman. Dover Publications, New York, New York, and American Wildlife Institute, Washington, DC, USA.

Received 17 February 2016

Accepted 21 October 2016

\section{SuPPlementary MATERIAL:}

VIDEO S1. Eastern Wolf (Canis sp. cf. lycaon) demonstrating food-caching behaviour in a Sphagnum bog, Algonquin Provincial Park, Ontario, Canada. Video by Hugo Kitching. https://youtu.be/Pj5hKJTMD5U. 